\title{
NUMERICAL VERIFICATION OF THE WOODEN STRUCTURE OF FORTIFIED SETTLEMENT FROM THE EARLY IRON AGE IN BISKUPIN WOJCIECH TERLIKOWSKI ${ }^{1}$, MARTYNA GREGORIOU-SZCZEPANIAK ${ }^{2}$, EWA SOBCZYŃSKA ${ }^{3}$ AND KACPER WASILEWSKI ${ }^{4}$
}

\begin{abstract}
Biskupin is one of the most recognizable archaeological site in Pola1nd and Central Europe. The origins of the excavations dates back to year 1934 and had lasted almost continuously until 1974. In the framework of the grant from the Ministry of Culture and National Heritage interdisciplinary team of scientists from Archaeological Museum in Biskupin and Warsaw University of Technology performed multi-dimensional analysis of the settlement. Based on the integrated vector documentation, resulting from the photographic documentation, numerical models of structural systems of main types of buildings and defensive rampart were prepared. The aim of the analysis was a verification of the earlier findings of archaeological and architectural researches. The analysis allowed to verify both the arrangement of individual parts of structure of buildings, their work and the interconnection, as well as the possible dimensions of the individual components.
\end{abstract}

Keywords: Architectural Heritage, Numerical Modelling, Timber Constructions

\section{INTRODUCTION}

One of the most spectacular achievements of the pre-war Polish archaeology was discovery of fortified settlement from the turn of the the Early Iron Age in Biskupin, site 4. The basic structures that shaped the settlement were wooden outer streets (Fig. 1: A), breakwaters (Fig. 1: B), defensive ramparts (Fig. 1: C, D, E), internal streets (Fig. 1: F), household buildings. The settlement was

\footnotetext{
${ }^{1}$ PhD., Eng., Warsaw University of Technology, Faculty of Civil Engineering, ul. Lecha Kaczyńskiego 16, 00-637 Warsaw, Poland, e-mail:w.terlikowski@il.pw.edu.pl

${ }^{2}$ Msc., Warsaw University of Technology, Faculty of Civil Engineering, ul. Lecha Kaczyńskiego 16, 00-637 Warsaw, Poland, e-mail: m.greg@il.pw.edu.pl

${ }^{3}$ Msc., Warsaw University of Technology, Faculty of Civil Engineering, ul. Lecha Kaczyńskiego 16, 00-637 Warsaw, Poland, e-mail:e.sobczynska@il.pw.edu.pl

${ }^{4}$ Msc., Warsaw University of Technology, Faculty of Civil Engineering, ul. Lecha Kaczyńskiego 16, 00-637

Warsaw,Poland, e-mail:k.wasilewski@il.pw.edu.pl
} 
destroyed and rebuilt two times during its existence [1]. Dendrochronological examinations proofed that the majority of wooden material used for structures of the buildings from the older phase of the settlement was cut out in years 739-736 BC [2].

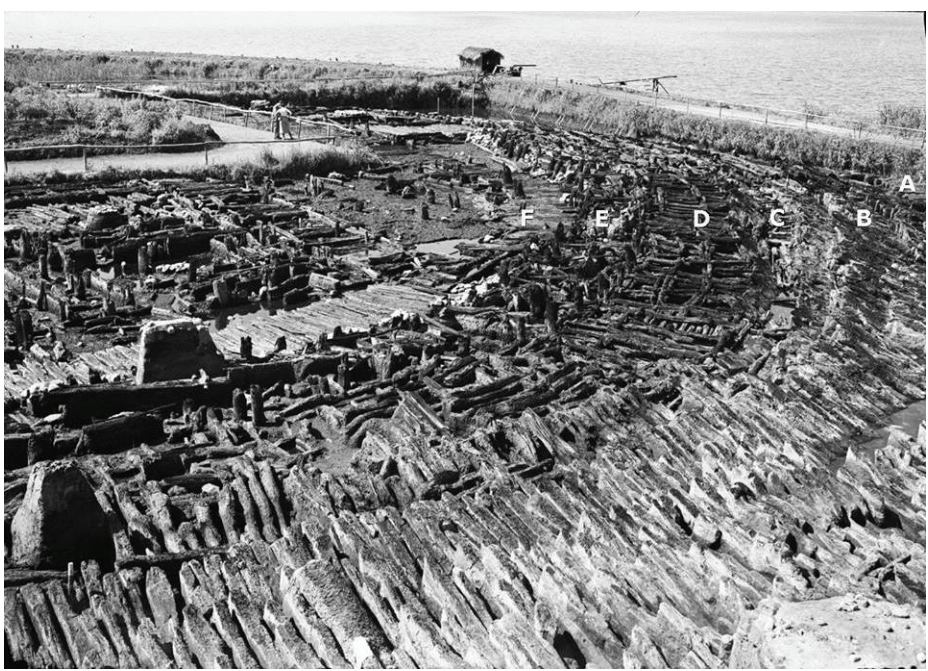

Figure 1. Biskupin, site 4. North-eastern part of the fortified settlement [3]. 


\section{PERFORMED ANALYSIS}

\subsection{GENERAL PURPOSE}

Objectives of the researches were: identification and verification of systems and structural solutions, determination of geometrical parameters of elements of the structural system used in Lusatian culture buildings in Biskupin as well as in defensive rampart. The analyzes were carried out on the model building presented in the literature [1] as well as the real one reconstructed on the basis of preserved documentation. The next aim was the evaluation of the influence of ground conditions on the work of the load bearing structure of analyzed buildings. Verification of structural solutions was carried out on a number of numerical models. In addition, an impact of some structural solutions on numerical models was assessed. The analyzed issues were: the influence of planks on the spatial rigidity of the building, the effect of the continuity of buildings and the influence of a landing on the buckling capacity of the internal column. The impact of ground conditions was assessed on the basis of numerical analysis of buildings with different susceptibility of theirs supports. Such approach appropriately reflects the real impact of ground substrate on the stiffness of the building.

\subsection{CONSTRUCTION OF BUILDINGS}

On the basis of literature analyses [1], the shape, dimensions and layout of the typical building in Biskupin were determined. There were considered different models, such as the collar beam hut, straight roof slope hut and the changeable roof slop hut (Fig. 2).

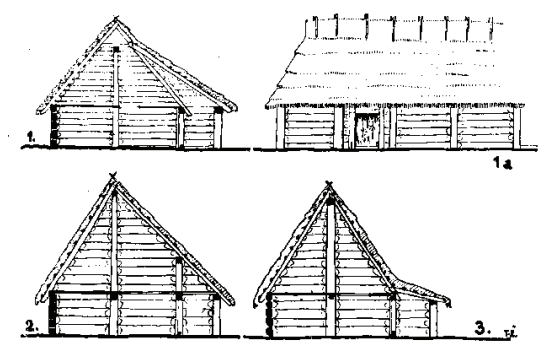

Figure 2. Reconstruction of building in Biskupin: 1.Collar beam hut. 2. Straight roof slop hut.

3. Changeable roof slop hut. [1] 
Finally, authors decided to choose the second of the proposed reconstructions. The preliminary analysis were performed on the model building according to Rajewski [1]. The building had a rectangular plan of $9.4 \times 9.2 \mathrm{~m}$ (Fig. 3). The following step of the analysis was structural assessment of the hut from the older phase of the settlement. The building was located at the end of a row of building (Fig. 4). The buildings were covered with double-pitched roof, with the structure created by rafters in a spacing of about $65 \mathrm{~cm}$ and the rectangular cross section of $8 \times 20 \mathrm{~cm}$, supported on the ridge beam and the gird beam on the longitudinal walls. The beams were assumed to be rectangular with dimensions of $20 \times 20 \mathrm{~cm}$ - ridge and $24 \times 24 \mathrm{~cm}$ - gird beam. The ridge was supported on rectangular posts of $14 \times 34 \mathrm{~cm}$ and $6.2 \mathrm{~m}$ in height. The structure of the wall consisted of rectangular planks of $19 \times 26 \mathrm{~cm}$ and rectangular posts of sizes depending on their location: corner posts $30 \times 30 \mathrm{~cm}$ and intermural posts $34 \times 14 \mathrm{~cm}$. The height of the longitudinal external walls was $2.1 \mathrm{~m}$.

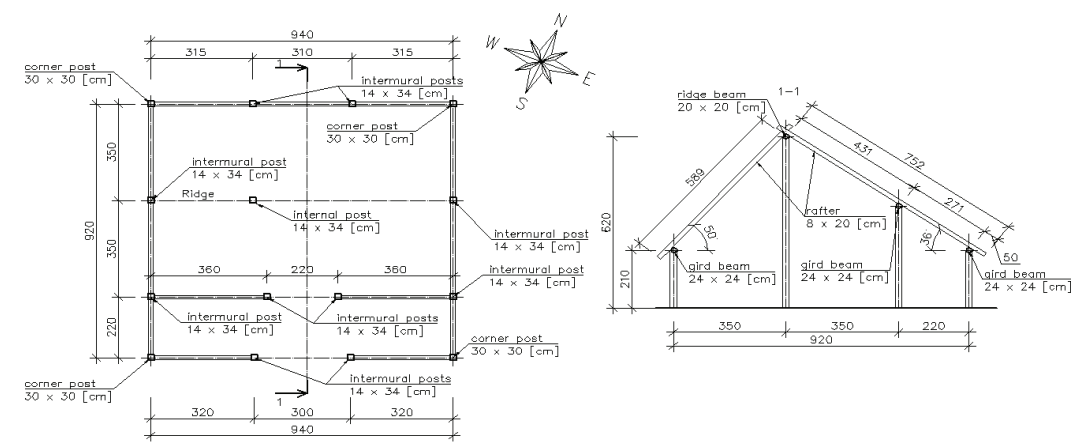

Figure 3. A projection and cross-section of a model building in Biskupin.

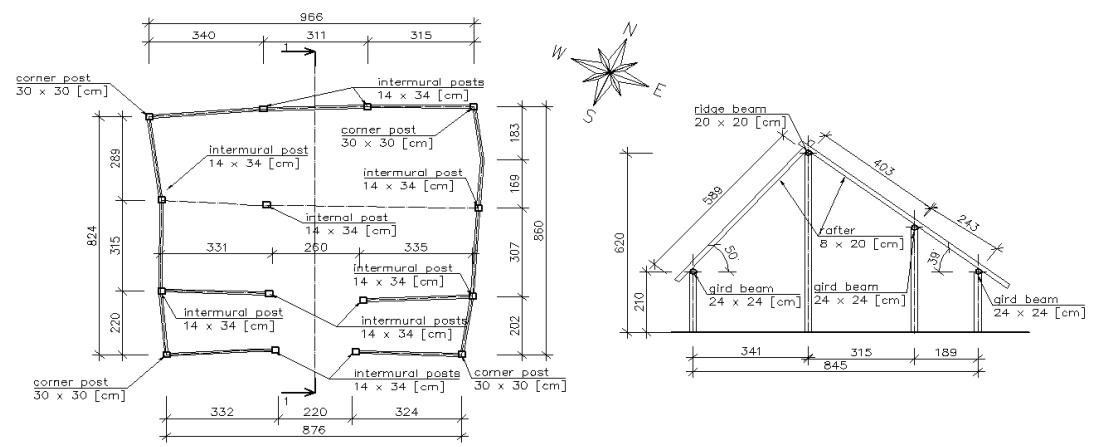

Figure 4. A projection and cross-section of a real building in Biskupin-older phase. 
In the younger phase the first analysed building (Fig. 5) has the post and plank structure and crosssections of structural elements analogous to those in older phase buildings. The second building (Fig. 6) has substitute post structural system and the roof structure made of rafters at a spacing of approx. $65 \mathrm{~cm}$ and sections $6.5 \times 14 \mathrm{~cm}$. The ridge beam and gird beam are also smaller in comparison to the previous structures, with dimensions of $12 \times 12 \mathrm{~cm}$ and $16 \times 16 \mathrm{~cm}$. The wall constructions consisted of rectangular planks of dimensions $10 \times 16 \mathrm{~cm}$ which were supported by posts with a diameter of $12 \mathrm{~cm}$. The height of the longitudinal external walls was $1.6 \mathrm{~m}$.

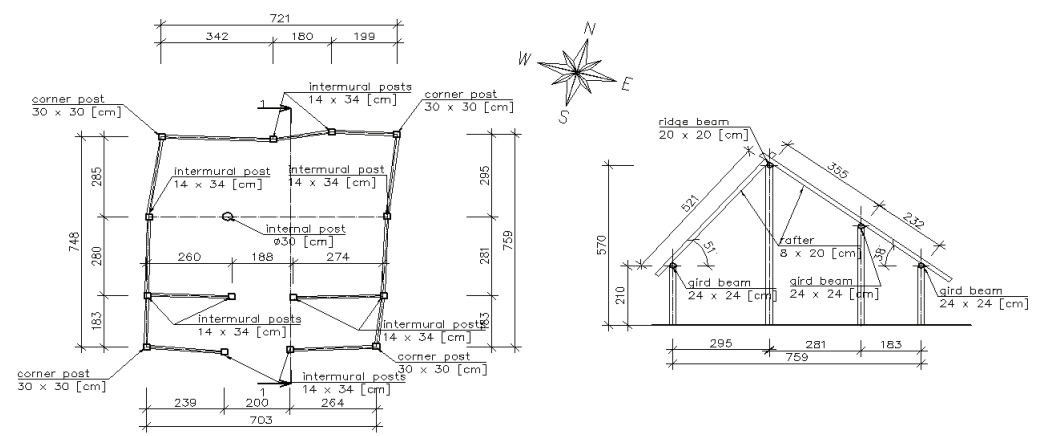

Rys.5 A projection and cross-section of a real building in Biskupin - younger phase, building located on ares: 47/48/60/61

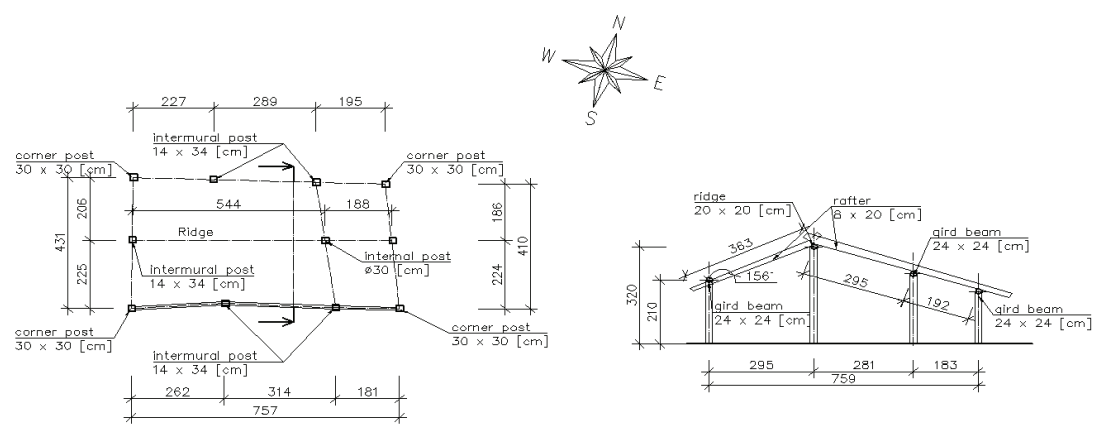

Rys. 6 A projection and cross-section of a real building in Biskupin - younger phase, building located in the eastern part of ares 48 and 61

Apart from buildings the structure of the defensive rampart was analyzed. It was made as a spatial wooden-ground construction from oak logs with a circular cross-section of about $20 \mathrm{~cm}$. The interior of the rampart was filled with cohesive and sandy soil. The cohesive soil, due to the low 
water permeability, worked as a protection against rapid rotting. The sandy soil stabilized the rampart, preventing from rotation and displacement.

\subsection{LOADS}

The numerical analysis carried out for the verification of wooden structures create the need to determine the values of forces acting on the buildings and defensive rampart. As a reasonable estimation the current European standards were used [5]. It was assumed that the weight of the structures was corresponded to the contemporary wooden structures made of $\mathrm{C} 27$ class wood. As a roof covering, a reed or straw on the patches was adopted. There was a need to simulate more severe than today's climatic conditions prevailing during the construction and use of the Biskupin settlement and take into account the location of the facilities on the shores of the lake. Such aims were achieved by applying the most unfavorable conditions to the buildings so such correspond to the buildings located directly on the seafront, which primarily affect the value of the wind load [4]. One of the elements of the analysis was to examine the influence of wind direction on structures. For this purpose, two directions were analysed - parallel and perpendicular to the ridge of the building. Due to the different roof slopes, snow loads are determined separately for each side of the roof.

For the calculation of the defensive rampart, the internal pressure of the soil and the static pressure of the water were taken into account. The objective of the calculations was to verify the assumed geometrical and material-construction assumptions of the box structure of the defensive rampart.

\subsection{MODELS}

As part of the analysis of Lusatian culture buildings structures numerous numerical models were prepared, which differs in terms of wind direction, implementation and degree of simplification of wall planks, number and type of huts in a row, and susceptibility of theirs supports. In the analyses, both real and substitute modeling of wall planks were used. Substitute stiffness was introduced by using props with stiffness corresponding to the total stiffness of planks. Substitute stiffening was not applied to the walls, which are loaded with wind pressure. Some numerical models mentioned above are shown in Table 1. Preliminary stage of the researches focused on the building of model geometry (Fig. 5) with analysis of an influence of several aspects. Model 1 is a structure without planks, with subtypes from 1.1 to 1.9 , characterized by varying stiffness of supports for displacement and rotation to determine the effect of these parameters on the work of the structural 
system. Model 2, with wind load perpendicular to the ridge, was modified by adding simplified planks across the

Table 1. Examples of numerical models of analysed huts

Number

building. In an analogous way, in model 3, loaded with wind parallel to the ridge, planks along the building were introduced. In models 4 and 5 the simplified wall stiffening was replaced with the real model of planks. The difference in deflection of buildings with and without planks is shown in Fig. 7. In the second stage the analysis were concerned on a row of buildings, consisting of three model huts. Model 6 was loaded with load perpendicular to the ridge, stiffened with real planks across the building, model 7 with planks along a raw of buildings. 


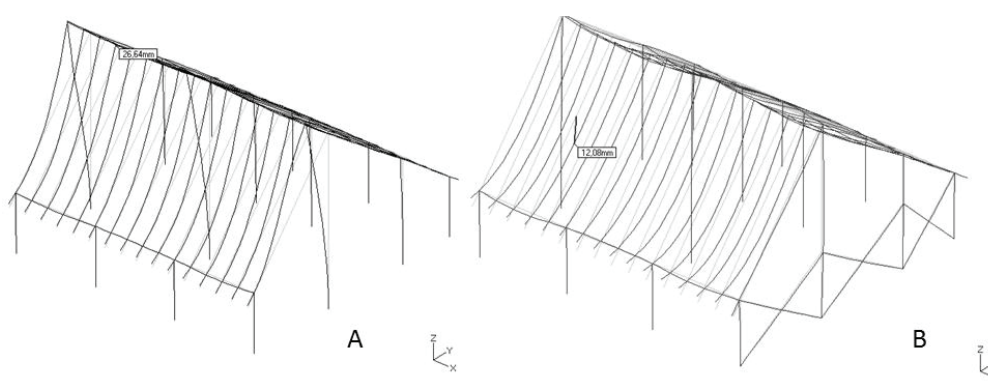

Figure 7. A - Deflection $\mathrm{XZ}$ of building without planks (wind perpendicular to the ridge),

B- Deflection XZ of building with simplified planks (wind perpendicular to the ridge)

At the next stage, the analysis were extended to four huts, a model 8 with real planks across the row and a model 9 with real planks along the buildings. The study was aimed at determining the dependence of the obtained results on the number of huts in a row. Fig. 8 presents the deflection of row of four buildings in comparison to single building. Next, a model of hut with real geometry reconstructed on the basis of preserved archaeological documentation was created (Fig. 4). The structure with wind load perpendicular to the ridge and real planks across the building - model 10 , parallel wind load and real planks along the building - Model 11, both with rigid supports were created. The next step was the analyse of the hut with the maximum spacing of the ridge supports according to preserved archival documentation, taking into account the differentiation due to the direction of the wind load and the susceptibility of the supports. Then study of the load bearing

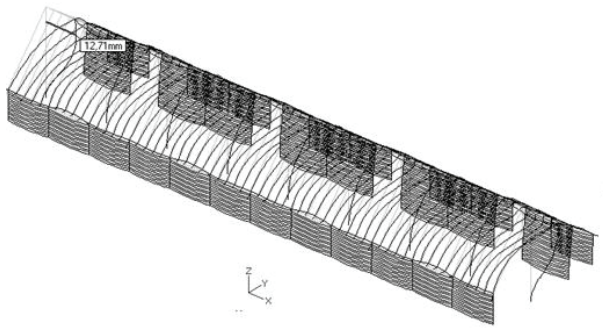

A

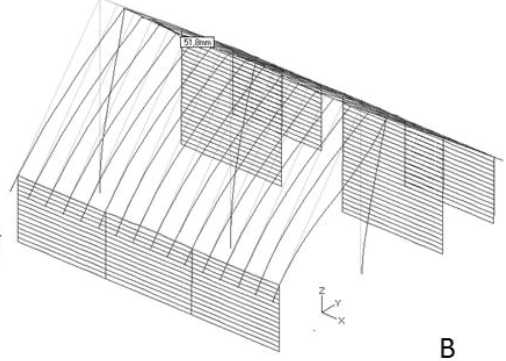

B

Figure 8. A - Deflection XZ of single building (wind parallel to the ridge), B- Deflection XZ of row of four buildings (wind parallel to the ridge).

capacity for buckling of the internal column with and without the landing, which fills a stiffening function was conducted. Then the buildings from younger phase were analysed, where also the influence of wind direction and susceptibility of theirs supports on the building were analyzed. 
The next structure, which was analyzed was the defensive rampart. The sizes of wooden elements of box structure of the rampart were verified. For this purpose, a numerical model of the gate part of the rampart with a length of approx. $3 \mathrm{~m}$ was created, which was loaded with the pressure of the ground located inside. Taking into account the static pressure of the water acting on the external wall of the defensive rampart, it was calculated that the estimated maximum height of the rampart of 5-6 $\mathrm{m}$ was possible. According to the calculations, the general stability conditions of the rampart are met at the maximum construction height of $13.7 \mathrm{~m}$. The results of selected calculations in the form of values and graphs of internal forces in the numerical model of box structure of the rampart are given in Fig. 9.
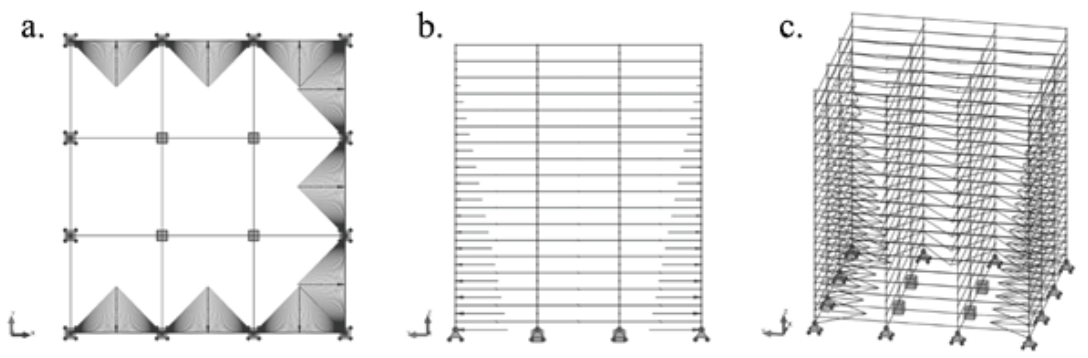

Figure 9. Static scheme of structure of rampart and loads adopted in the analysis: a. - top view; b. - side view; c. - 3-d view (Autodesk Robot Structural Analysis)

\section{CONCLUSION OF PERFORMED ANALYSES}

Models 1-5 have illustrated the effect of planks on the work of the entire structure. Planks not only protect the interior of the buildings against changing atmospheric conditions, but they are also important structural stiffening elements. Models 6-9 show that the second significant stiffening solution was the connection of buildings in rows. As a result, each individual hut in row of buildings shows smaller deflections than the free-standing building. Analyses of the conducted numerical models, especially subtypes 1.1 to 1.9 , show that the most influencing factor on the structure is the susceptibility of its supports and therefore the soil on which it is located. The calculation confirmed the need for an intermediate beam supporting the inner column at the level of the landing. Moreover the internal post had to be made of oak wood (having better mechanical properties, including compressive strength along fibers and bending) or, when made of pine wood, have a diameter of more than $30 \mathrm{~cm}$. An alternative to this is statement that the total height had to be less than assumed in the studies. 
Numerical analysis of the defensive rampart showed that the assumptions adopted for analysis, based on the findings of previous tests (for example the original height of the rampart) were also correct. Such structure filled with soil, especially some cohesive one, is a stable construction that meets the principle of stability for travel and rotation. At the same time, it is a flexible, so that uneven settlement does not significantly affect its technical condition (construction safety).

\section{REFERENCES}

1. Rajewski Z. pod red. Kostrzewski J., „Budowle kultury łużyckiej na półwyspie jeziora biskupińskiego. III Sprawozdanie z prac wykopaliskowych w grodzie kultury łużyckiej w Biskupinie w powiecie Żnińskim za lata 1938-1939 i 1946-1948”, Poznań, 1950.

2. Ważny T., „Dendrochronologia drewna biskupińskiego, czyli co drzewa zapisały w przyrostach rocznych”, (in.:) L. Babiński (edit.), „Stan i perspektywy zachowania drewna archeologicznego”, Biskupińskie Prace Archeologiczne, No. 7, p. 63-76, 2004.

3. Archives of the Archaeological Museum in Biskupin.

4. Pazlar T.,M.Kramar, "Traditional timber structures in extreme weather conditions" International Journal of Architectural Heritage, 18 August 2015

5. Larsen J., "Practical design of timber structures to Eurocode 5", Londyn, 2009

\section{LIST OF FIGURES:}

Fig. 1. Biskupin, site 4. North-eastern part of the fortified settlement

Rys. 1. Biskupin, stanowisko 4. Północno-wschodnia część grodu

Fig. 2. Reconstruction of building in Biskupin : 1.Collar beam hut. 2. Straight roof slop hut. 3. Changeable roof slop hut

Rys. 2. Rekonstrukcja domu biskupińskeigo: 1. Chata jętkowa.2. Chata o dachu gładkim.3. Chata o dachu załamanym.

Fig. 3. A projection and cross-section of a model building in Biskupin.

Rys. 3. Rzut i przekrój modelowego domu biskupińskiego

Fig. 4. A projection and cross-section of a real building in Biskupin-older phase.

Rys. 4. Rzut i przekrój rzeczywistego domu biskupińskiego - faza starsza

Fig. 5. A projection and cross-section of a real building in Biskupin - younger phase, building located on ares: $47 / 48 / 60 / 61$

Rys. 5. Rzut i przekrój rzeczywistego domu biskupińskiego - faza młodsza, budynek na arach: 47/48/60/61

Fig. 6. A projection and cross-section of a real building in Biskupin - younger phase, building located in the eastern part of ares 48 and 61

Rys. 6. Rzut i przekrój rzeczywistego domu biskupińskiego - faza młodsza, budynek na arach 48 i 61 Rys. 7.

Fig. 7. Deflection XZ of building without planks (wind perpendicular to the ridge), B- Deflection XZ of building with simplified planks (wind perpendicular to the ridge) 
Rys. 7. A - Ugięcie XZ budynku bez sumików (wiatr prostopadły do krokwi), B- Ugięcie XZ budynku z uproszczonymi sumikami (wiatr prostopadły do krokwi)

Fig. 8. A - Deflection XZ of single building (wind parallel to the ridge), B- Deflection XZ of row of four buildings (wind parallel to the ridge).

Rys. 8 . Ugięcie XZ pojedynczego budynku (wiatr równoległy do krokwi), B- Ugięcie XZ szeregu budynków (wiatr prostopadły do krokwi)

Fig. 9. Static scheme of structure of rampart and loads adopted in the analysis: a. - top view; b. - side view; c. - 3-d view (Autodesk Robot Structural Analysis)

Rys. 9 . Schemat obciążeń przyjęty w analizie: a. - widok z góry; b. - widok z boku; c. - widok 3-d (program komputerowy Autodesk Robot Structural Analysis) 


\section{NUMERYCZNA WERYFIKACJA DREWNIANYCH ZABUDOWAŃ GRODU Z WCZESNEJ EPOKI ZELAZA W}

\section{BISKUPINIE}

Stowa kluczowe: dziedzictwo architektoniczne, modelowanie numeryczne, konstrukcje drewniane

\section{STRESZCZENIE:}

Jednym z najbardziej spektakularnych osiągnięć przedwojennej polskiej archeologii było odkrycie grodu z przełomu epoki brązu i wczesnej epoki żelaza w Biskupinie, stanowisko 4. Podstawowymi drewnianymi konstrukcjami kształtującymi zabudowę tego terenu były zewnętrzne ulice, falochrony, mury obronne, ulice wewnętrzne i budynki gospodarcze. Gród został zniszczony i odbudowany dwukrotnie podczas swojego istnienia. Badania dendrochronologiczne dowodzą, że większość materiału drewnianego użytego do budowy budynków ze starszej fazy osady została wycięta w latach 739-736 p.n.e. W ramach grantu Ministra Kultury i Dziedzictwa Narodowego interdyscyplinarny zespół naukowców z Muzeum Archeologicznego w Biskupinie i Politechniki Warszawskiej przeprowadził wielowymiarową analizę zabudowy. Na podstawie zintegrowanej dokumentacji wektorowej, powstałej w oparciu o dokumentację fotograficzną, opracowano modele numeryczne układów konstrukcyjnych głównych typów budynków zarówno z etapu starszego, jak i młodszego oraz wału obronnego. Celem badań była identyfikacja i weryfikacja układów i rozwiązań konstrukcyjnych, określenie parametrów geometrycznych elementów tworzących układ konstrukcyjny wykorzystywany w budynkach kultury łużyckiej w Biskupinie jak i konstrukcji wału obronnego. Kolejnym celem była ocena wpływu warunków gruntowych na pracę konstrukcji nośnej analizowanych budynków. Ponadto oceniano wpływ niektórych rozwiązań konstrukcyjnych, takich jak wpływ sumików na sztywność przestrzenną budynku, wpływ ciągłości zabudowy i wpływ półpiętra na nośność wyboczeniową słupa wewnętrznego. Analizy przeprowadzono na modelu budynku przedstawionym w literaturze(Rys. 2), a także zrekonstruowanym na podstawie zachowanej dokumentacji. Ostatecznie autorzy postanowili wybrać chatę z jednakowym nachyleniem połaci do dalszej analizy. Budynki kultury łużyckiej miały strukturę sumikowo-łątkową - pojedyncze sumiki wstawiano do pionowych rowków wyżłobionych w łątkach, łączonych razem na górze i na dole. W młodszej fazie można również wyróżnić także konstrukcję łątki zastępczej. Budynki łączone były szeregowo, co umożliwiło wykorzystanie ściany szczytowej jako wspólnej ściany konstrukcyjnej i jednocześnie zmniejszało zużycie surowca.

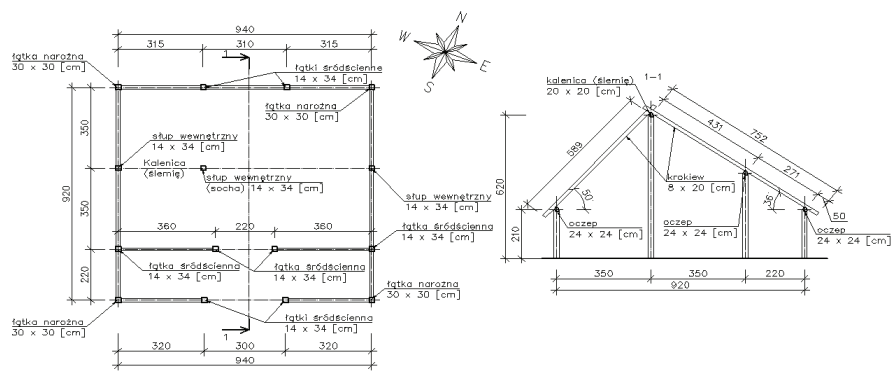

Rysunek 1. Rzut i przekrój modelowego budynku w Biskupinie 
Oprócz budynków przeanalizowano konstrukcję wału (Rys. 2). Wał wykonany jest w przestrzennej konstrukcji drewniano-gruntowej z dębowych bali o przekroju kołowym, o średnicy ok. $20 \mathrm{~cm}$. Wnętrze wału wypełnione było gruntem spoistym i piaszczystym. Grunt spoisty, ze względu na małą przepuszczalność wody, stanowił jednocześnie zabezpieczenie konstrukcji drewnianej przed szybkim butwieniem. Wypełnienie kaszycy gruntem stabilizowało ja statecznie, zapobiegając obrotowi i przesunięciu.

a.

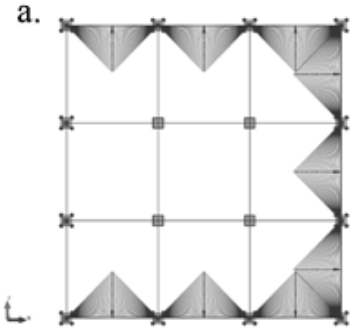

b.

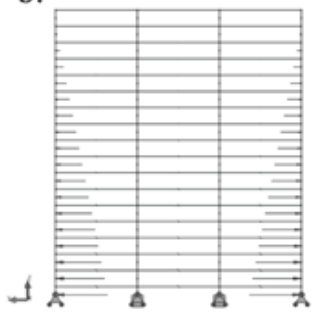

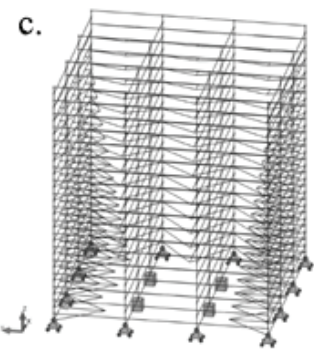

Rysunek 2. Schemat obciążeń przyjęty w analizie: a. - widok z góry; b. - widok z boku; c. - widok 3-d

\section{WNIOSKI:}

Pierwsze pięć modeli ilustruje wpływ sumików na pracę całej konstrukcji, które nie tylko chronią wnętrze budynków przed zmieniającymi się warunkami atmosferycznymi, ale także są ważnymi elementami usztywniającymi konstrukcję. Następne cztery modele pokazują, że drugim ważnym rozwiązaniem usztywniającym było połączenie budynków w rzędy. W rezultacie każda pojedyncza chata w rzędzie wykazuje mniejsze ugięcia niż wolnostojący budynek. Analizy przeprowadzonych modeli numerycznych o różnej podatności podpór pokazują, że czynnikiem najbardziej wpływającym na konstrukcję jest podłoże, na którym jest on posadowiony. Ponadto musiał być on wykonane z drewna dębowego (posiadającego lepsze właściwości mechaniczne, w tym wytrzymałość na ściskanie wzdłuż włókien i zginanie) lub, w wypadku wykonania z drewna sosnowego, mieć przekrój o średnicy większej niż $30 \mathrm{~cm}$. Alternatywa do tego jest stwierdzenie, że ich wysokość musiała być mniejsza niż założona w badaniach. Analiza numeryczna konstrukcji wału wykazała, że przyjęte do analiz założenia, bazujące na ustaleniach badań wcześniejszych (np. wysokość pierwotna wału) były również właściwe. Konstrukcja taka wypełniona gruntem, zwłaszcza gruntem spoistym jest konstrukcja stabilną, spełniającą zasadę stateczności na przesuw i obrót. Jest to jednocześnie konstrukcja na tyle elastyczna, że nierównomierne osiadanie nie wpływa znacząco na jej stan techniczny (bezpieczeństwo konstrukcji). 